\title{
DISKURSUS NILAI MINIMAL HARTA CURIAN DALAM HUKUM PIDANA ISLAM
}

\author{
Salma \\ Universitas Islam Negeri Imam Bonjol Padang \\ salma@uinib.ac.id
}

\begin{abstract}
The value of Indonesian rupias in KUHP has decreased time by time and it couldnot survive over 57 years passed away. Oppositely, minimum value of the stolen property in Islamic criminal law has survived over 1438 years old. This article explored the concept of the minimum value (nisâb) for the stolen property which are accounted in gold and silver money in detail and how the jurists explained its factors.Very early in the development of Islamic law, the Hanafi's school set the minimum value at five dirham. Other jurists, however, preferred minimum value at a dinar or ten dirhams. This became the dominant rule in the Hanafi's doctrine. In the Syafi'iy, Maliki, and Hanbali's schools, the minimum value must be $1 / 4$ dinar or three dirhams. As a result, the jurists established their respective minimum to reinforce the point that the hadd penalty applied only to thefts of rather major proportions. By using gold and silver in counting minimum and maximum the stolen property in Islamic law is always useful and appropriate in any periods. Some Muslim countries in the world have applied the rule. The paper is based primarily on library research and used the content analysis to examine the texts.
\end{abstract}

Keywords:

Nisâb, theft, property, cutting hand

\begin{abstract}
Abstrak
Nilai rupiah pada pidana pencurian dalam KUHP terus menurun dan tidak mampu bertahan setelah lebih dari 57 tahun berlalu. Sebaliknya, nisâb harta curian dalam hukum pidana Islam tetap bertahan dalam usianya yang ke 1440 tahun. Dalam tulisan ini dikemukakan konsep nisâb dalam pencurian secara terperinci dan faktor-faktor yang membuat ketentuan ini tetap bertahan dan bisa digunakan dalam keadaan apapun. Mazhab Hanafi menetapkan 5 dirham sebagai nisâb harta curian. Kalangan ulama Hanafiah lainnya menetapkan 1 dinar atau 10 dirham sebagai nilai minimal nisâb harta curian dan menjadi pendapat terkuat di kalangan mereka. Adapun
\end{abstract}


ulama mazhab Syafi'iy, Maliki, dan Hanbali menetapkan $1 / 4$ dinar atau 3 dirham sebagai nisâb harta curian. Standar emas dan perak yang digunakan untuk menghitung nilai harta curian dalam hukum Islam senantiasa berguna dan sesuai sepanjang masa. Beberapa negara Muslim di dunia menggunakan ketentuan ini sampai sekarang. Kajian ini dilakukan dengan menggunakan sumber kepustakaan dan dilakukan analisis isi pada setiap teks yang berkenaan.

\section{Kata Kunci:}

Nisāb; Pencurian; Properti; Pemotongan Tangan

\section{A. PENDAHULUAN}

Mahkamah Agung Republik Indonesia mengeluarkan Peraturan MA RI Nomor 02 Tahun 2012 Tentang Penyesuaian Batasan Tindak Pidana Ringan dan Jumlah Denda Dalam KUHP. ${ }^{1}$ Sejak tahun 1960 seluruh nilai uang yang terdapat dalam KUHP belum pernah disesuaikan kembali. Hal ini berimplikasi pada pasal pencurian biasa yang diatur dalam pasal 362 KUHP atas tindak pidana yang diatur dalam pasal 364 KUHP dengan batas minimal nilai harta curian yaitu Rp.25.- (dua puluh lima rupiah). ${ }^{2}$ Akhirnya, jika nilai uang yang ada dalam KUHP tersebut disesuaikan dengan kondisi saat ini maka penanganan perkara tindak pidana ringan seperti pencurian ringan, penipuan ringan, penggelapan ringan dan sejenisnya dapat ditangani secara proporsional.

Sejak tahun 1960 (57 tahun yang lalu), nilai rupiah telah mengalami penurunan yang luar biasa sekitar 10.000 (sepuluh ribu) kali dibanding harga emas

1 Nama Kitab Undang-undang Hukum Pidana berasal dari bahasa Belanda Wetboek van Strafrecht yang ditetapkan berdasarkan S.1915-732 jis.S. 1917-497, 645. Sebutan Kitab Undang-undang Hukum Pidana ini diberlakukan, diubah dan ditambah dengan Undang-undang 1/1946 (Berita Republik Indonesia II, 9). Undang-undang ini mengadakan perubahan/tambahan terhadap W.v.S Ned. Ind, yaitu Hukum Pidana 8 Maret 1942. Jadi bukan terhadap hukum pidana zaman Jepang dan bukan pula terhadap W.v.S. Ned. Ind. Yang sudah diubah dan ditambah oleh pemerintah Belanda sesudah 1945 (S. 1945-135, S. 1946-76, S. 1947-180, S. 1948-169, S. 1949-1 dan 258). Kemudian diubah dan ditambah lagi berturut-turut dengan UU 1/1946, UU 20/1946, UU8/1951, UU 8/Drt/1955, UU 73/1958, UU 1/1960, Perpu 16/1960, Perpu 18/1960, Penpres 1/1965, Penpres 7/1974, Penpres 4/1976, dan UU 27/1999. Lihat Harun Alrasid (pem.red), Himpunan Peraturan Perundang-undangan Republik Indonesia Menurut Sistem Engelbrecht, Jilid I, (Jakarta: Ichtiar Baru van Hoeve, 2006), 1701

2 Pasal 362 KUHP menyebutkan:"Barang siapa mengambil suatu barang, yang seluruhnya atau sebagian kepunyaan orang lain, dengan maksud untuk memilikinya secara melawan hukum, diancam karena pencurian dengan pidana penjara paling lama lima tahun atau pidana denda paling banyak sembilan ratus rupiah". Pasal 364 menyebutkan:"...jika harga barang yang dicuri tidak lebih dari dua puluh lima rupiah, diancam karena pencurian ringan dengan pidana penjara paling lama tiga bulan atau pidana denda paling banyak tiga ribu tujuh ratus lima puluh rupiah. Lihat ibid., 1742 
ketika itu, sehingga perlu disesuaikan dengan nilai rupiah sekarang ini. Hal ini menunjukkan bahwa nilai uang selain emas dan perak secara faktual tidak begitu mudah untuk dapat menyesuaikan diri dengan perkembangan zaman. Jika dilihat kembali konsep nisâb harta curian yang berakibat hukuman potong tangan dalam hukum pidana Islam, dengan tujuan untuk menilai kebergunaannya dalam pematangan hukum pidana Indonesia yang sampai saat ini masih dalam proses rancangan.

Mayoritas ulama berpendapat bahwa nisâb ialah salah satu syarat untuk bisa dilaksanakannya hukuman potong tangan. Orang pertama yang dihukum potong tangan karena mencuri pada zaman jahiliyah ialah al-Walid ibn al-Mughirah. Kemudian Allah SWT memerintahkan pelaksanaan hukuman potong tangan dalam syariat Islam. Pencuri pertama yang dipotong tangannya oleh Rasulullah SAW ialah al-Khiyar ibn 'Adiy ibn Naufal ibn Abd Manaf. Sedangkan dari kalangan perempuan ialah Murrah bt Sufyan ibn Abd al-Asad dari kalangan Bani Makhzûm. Pada generasi seterusnya para Sahabatpun melaksanakan hukuman potong tangan ini. ${ }^{3}$ Sekalipun mereka berbeda pendapat mengenai batas pemotongan tangan dan kemestian memotong kedua tangan dan kedua kaki pada pencurian yang dilakukan berulang kali.

Hukuman potong tangan ini dapat dilaksanakan ketika telah terpenuhi syarat-syarat yang diperlukan. Salah satunya ialah harta curian telah mencapai ukuran nisâb ketika dicuri. Para ahli fiqh berbeda pendapat mengenai nisâb harta curian ini. Di antara penyebab terjadinya perbedaan pendapat ini ialah adanya berbagai riwayat yang menjelaskan nisâb yang berbeda. Perbedaan-perbedaan itu dapat dikategorikan sebagai berikut: 1). Ada ahli fiqh yang mengatakan bahwa batas minimal harta curian ialah 1/4 dinar (فى ريع دينار) atau senilai dengan harga 1/4 dinar ketika harta itu dicuri. Pendapat ini dipegang oleh ahli fiqh mazhab Shafi'iy dan mayoritas ulama mazhab Hanbali. 2). Ada yang mengatakan $1 / 4$ dinar atau 3 dirham atau nilainya sama dengan 3 dirham ketika harta itu dicuri. ${ }^{4}$ Pendapat ini dipegang oleh ulama mazhab Maliki. 3). Ada yang mengatakan 10 dirham atau senilai dengan 10 dirham ketika harta itu dicuri dan menyandarkan batas minimal harta curian kepada harga المجن (tameng untuk berperang) yang pada masa itu nilainya berbedabeda. Pendapat ini dipegang oleh ulama mazhab Hanafi.

Mayoritas ahli fiqh berpendapat bahwa seorang pencuri tidak dipotong tangannya kecuali harta curiannya mencapai ukuran nisâb. Di antara banyak perawi hadis seperti imam al-Bukhariy dan Muslim, meletakkan hadis-hadis في ربع دينار pada urutan yang paling sahih, setelah itu baru mencantumkan hadis-hadis lain seperti

${ }^{3}$ Muhammad Najib al-Mutî'iy, Kitâb al-Majmû' Syarh al-Muhazzab li al-Syirâziy, Juz 19, (alFijâlah, al-Maktabah al-Alamiyah., t.th), 5

${ }^{4}$ Ibn Qudâmah, al-Mughniy, wa al-Syarh al-Kabîr ala Matan al-Qan'u fi Figh al-Imâm Ahmad ibn Hanbal, Jilid 10, (Beirût: Dâr al-Fikr, 1984), 235. 
hadis yang mengandung perkataan فى ثمن المجن. Semua hadis ini dijadikan sebagai dalil untuk menentukan batas minimal harta curian agar dapat dilakukan hukuman potong tangan pada pencuri tersebut. Namun penggunaan hadis ini berbeda di antara para ulama.

Berbeda ulama, berbeda hadis-hadis yang digunakan, maka terjadi berbagai penafsiran terhadap kewajiban hukuman potong tangan. Akibatnya tidak wajib وقع الإحتمال فى وجوب القطع فلا يجب (م) و وفع الاحت في karena mencuri. Jika hal itu digunakan sebagai ukuran dalam pencurian kali pertama, maka dipotong tangan si pencuri, karena terpenuhi syarat yaitu sempurnanya nisâb. Jika diperdebatkan tentang pencuriannya, maka tidak dipotong tangan pencuri karena ketiadaan syarat. Untuk lebih jelas sebab-sebab perbedaan pendapat itu dapat dilihat dalam penjelasan berikut ini.

\section{B. RESISTENSI NISÂB HARTA CURIAN MENURUT MAZHAB HANAFI}

Ulama mazhab Hanafi membicarakan kedudukan surat al-Mâidah (5): 38 yaitu:

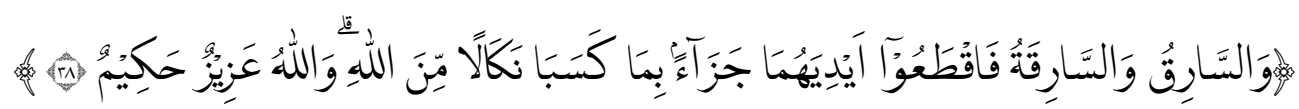

Terjemahnya:

Adapun orang laki-laki maupun perempuan yang mencuri, potonglah tangan keduanya (sebagai) balasan atas perbuatan yang mereka lakukan dan sebagai siksaan dari Allah. Dan Allah Mahaperkasa, Mahabijaksana. ${ }^{6}$

Laki-laki yang mencuri dan perempuan yang mencuri, potonglah tangan keduanya (sebagai) pembalasan bagi apa yang mereka kerjakan dan sebagai siksaan dari Allah. dan Allah Maha Perkasa lagi Maha Bijaksana.

Mereka mengemukakan bahwa lafal والسارق والسارقة فاقطعو آيديهما dalam surat alMâidah ayat 38 di atas ialah mujmal (مجمل). Mereka mengawali pembicaraan dengan mengatakan bahwa ayat ini bersifat khusus, karena perkataan السرقة bisa dijumpai dalam lafal mencuri dengar dalam surah al-Hijr (15): 18 sebagai berikut:

Terjemahnya :

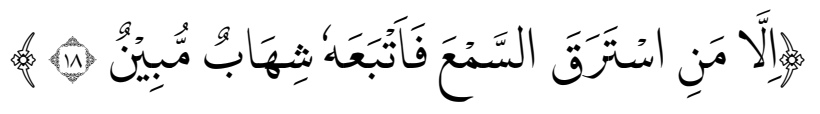

Kecuali (setan) yang mencuri-curi (berita) yang dapat didengar (dari $342 \& 343$.

${ }^{5}$ Ibn al-Humâm al-Hanafiy, Syarh Fath al-Qadîr, Juz 5, (Beirût: Dâr al-Kutub al-Ilmiyah, 1995),

\footnotetext{
${ }^{6}$ Al-Qur ân, al-Mâidah (5): 38
} 
malaikat) lalu dikejar oleh semburan api yang terang. ${ }^{7}$

Kecuali (setan) yang mencuri-curi (berita) yang dapat didengar (dari malaikat) lalu dikejar oleh semburan api yang terang.

Pada ayat ini Allah SWT menggunakan lafal سرقة untuk menyatakan adanya perbuatan mencuri suatu benda yang ada tetapi tidak bisa disentuh (abstrak). Penggunaan kata ini dilatarbelakangi oleh perbuatan setan yang mencuri dengar secara sembunyi-sembunyi berdasarkan lafal استرق. Perkataan ini selaras dengan pengertian السرقة sebagai perbuatan mengambil harta orang lain secara sembunyisembunyi atau tidak dengan sepengetahuan pemiliknya. Selain itu, perkataan yang sama juga bisa dijumpai dalam lafal mencuri shalat dalam hadis Rasulullah SAW sebagai berikut:

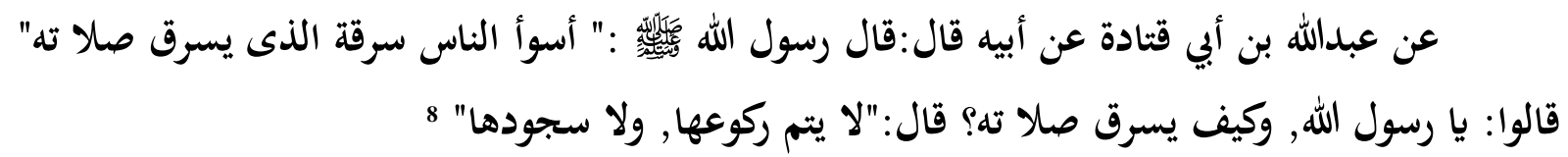

Artinya:

Hadis diterima dari Abdullah ibn Qatâdah dari ayahnya ia berkata: Rasulullah SAW bersabda:"Seburuk-buruk pencurian oleh manusia ialah orang yang mencuri shalatnya." Para sahabat bertanya: Wahai Rasulullah, bagaimanakah seseorang mencuri shalatnya? Rasulullah menjawab:"Tidak disempurnakan rukuk dan sujudnya."

Rasulullah SAW dalam hadis ini menggunakan perkataan سرقة untuk perbuatan mencuri shalat. Perkataan ini dilatarbelakangi oleh sikap seseorang dalam shalat, baik dalam rukuk maupun dalam sujud yang tidak diketahui oleh orang lain. Orang melakukan perbuatan ini secara diam-diam dan tidak diketahui oleh orang lain, sehingga perbuatannya disebut dengan istilah السرقة. Berdasarkan ayat al-Qur'an dan Sunnah di atas, maka perkataan السرقة ialah tutur kata yang dipahami maknanya oleh orang yang menggunakannya, sehingga perkataan itu tidak memerlukan lebih penjelasan. Demikian juga hukumnya dalam pengertian syarak. Hanya saja perkataan ini dikaitkan dengan hukum القطع, seperti halnya perkataan الإجارة ,النكاح ,البيع, dan perkataan-perkataan lain yang makna bahasanya bisa dipahami akal dengan mudah. Jika aspek-aspek ini dikaitkan dengan hukum-hukum tertentu, maka yang dipandang adalah keumumannya sesuai dengan penyebutannya, kecuali ada dalil lain yang menjelaskan kekhususannya. Zahir firman Allah SWT والسارق والسارقة ialah keharusan untuk mengamalkan hukum selaras dengan umumnya penyebutan lafal itu, kecuali ada dalil yang mengkhususkannya.

Menurut ulama mazhab Hanafi, sifat umum hukum ayat ini berkaitan dengan makna selain penyebutan yang wajib untuk diperhatikan yaitu الحرز (tempat

\footnotetext{
7 Al-Qur'ân, al-(5): 38

${ }^{8}$ al-Dârimiy, Sunan al-Dârimiy, Juz 1, (Kairo: Dâr al-Hadîth, 2000), 321.
} 
terpelihara harta yang dicuri) dan المقدار (ukuran minimal harta yang dicuri). Artinya, lafal ayat ini bersifat مجمل dari segi المقار yang menghendaki penjelasan lain. Jadi, itu tidak bisa dari sisi tersebut untuk memandang keumumannya tentang kewajiban hukuman potong tangan pada keseluruhan ukuran pengambilan harta (sedikit atau banyak). ${ }^{9}$ Hukuman potong tangan bisa dilakukan dengan mempertimbangkan jumlah minimal harta yang dicuri atau hukuman potong tangan bergantung pada jumlah harta yang dicuri. Mereka mengatakan bahwa lafal ayat ini bersifat مجمل dari segi المقدارyang menghendaki penjelasan lain. Alasan tentang ijmal-nya ayat ini dan terhalang memandang keumumannya ialah sebagai berikut:

1. Hadis-hadis yang menjelaskan batas minimal harta curian, di antaranya ialah sebagai berikut:

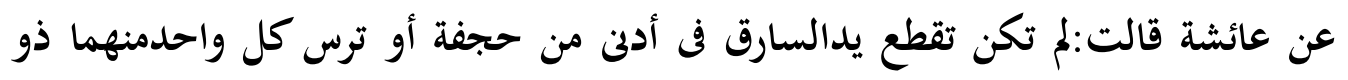

Artinya :

Hadis diriwayatkan dari 'Aisyah beliau berkata: Tidak dipotong tangan pencuri yang mencuri kurang dari harga hajafah atau turs (baju perang) yang masing-masing dari keduanya mempunyai harga.

Selain itu juga ada hadis lainnya yaitu:

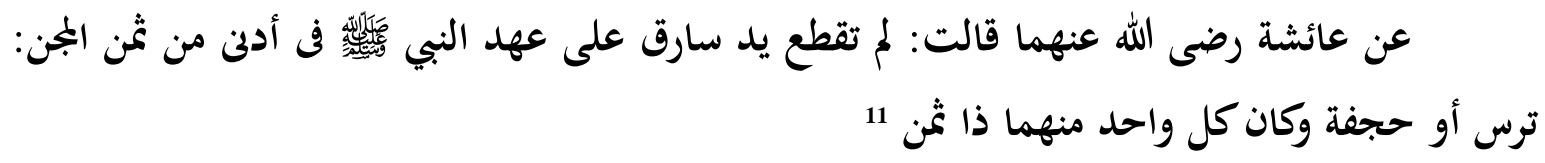

Artinya :

Hadis diriwayatkan dari Aisyah ia berkata: Tidak dipotong tangan seorang pencuri pada masa Nabi SAW yang mencuri kurang dari harga al-mijann, turs atau hajafah yang masing-masing dari keduanya mempunyai harga.

Kedua hadis di atas menjelaskan bahwa hukuman potong tangan seperti yang diperintahkan dalam ayat فاقطعو آيديهما tidak bisa langsung dilaksanakan karena hadis ini membatasi pelaksanaan hukuman itu dengan menyebutkan ukuran minimal harta yang dicuri. Perkataan ثمن المجن terdiri dari dua kata yaitu ثمن dan المجن. Perkataan ثمن atau harga (berharga/bernilai), karena segala sesuatu benda itu dikenali dan dibatasi dengan satu harga, tidak dengan beragam harga. Adapun perkataan المجن bermakna sebuah benda yang terbuat dari kayu atau tulang-belulang yang dibalut dengan kulit untuk melindungi diri dalam

${ }^{9}$ al-Jassâs, Tafsîr Ăyât al-Ahkâm, (Beirût: Dâr al-Fikr, t,th), 416.

10 al-Bukhâriy, Sahîh al-Bukhâriy, Juz 4, (Kairo: Dâr al-Hadîth, 2000), 402.

${ }^{11}$ Ibn Hajar al-'Asqalâniy, Fath al-Bâriy Syarh Sahîh al-Bukhâriy, Jilid 12, (Kairo: Dâr al-Manâr, 1999), 111. 
peperangan. ${ }^{12}$ Benda ini mempunyai harga yang beragam sesuai dengan kualitasnya ketika itu. Harga-harga المجن ini dijumpai dalam berbagai hadis. Berdasarkan hadis-hadis tersebut, terukur bahwa hukum ayat tentang kewajiban memotong tangan pencuri bergantung kepada ثمن المجن. Dengan demikian turunnya hadis bersamaan masanya dengan turunnya ayat yang keberadaannya saling menjamin antara satu dengan lainnya. Oleh sebab itu penafsiran lafal ayat tersebut ialah:

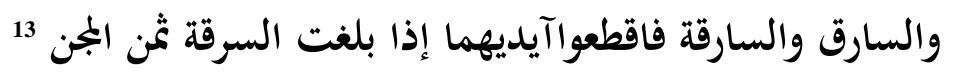

Artinya :

Lelaki yang mencuri dan perempuan yang mencuri maka potonglah olehmu tangan mereka apabila harta curiannya mencapai harga al-mijann.

Mungkin pernyataan ini belum memadai untuk menjelaskan ketetapan hukum ayat, tetapi tidak dapat juga menjadi metode yang tepat untuk beralasan (berdalil) dengan keumumannya.

2. Pendirian ulama-ulama salaf tentang harga المجن

Para ulama salaf mempunyai pendirian yang berbeda-beda tentang harga المجن. Misalnya Abdullah ibn Abbas, Abdullah ibn Umar, Aiman al-Habshiy, Abu Ja'far, Ata', Ibrahim, dan lain-lain mengatakan bahwa harga المجن ialah 10 dirham. Ibn Umar mengatakan 3 dirham. Menurut Anas, Urwah, al-Zuhriy, Sulaiman ibn Yasar mengatakan 5 dirham dan menurut Aisyah 1/4 dinar. Semua harga itu bukanlah harga keseluruhan المجن, karena harganya berbeda-beda seperti berbedanya harga pakaian dan harta benda lainnya. Secara faktual, ini adalah ragam harga المجن yang menjadi ukuran (minimal) potong tangan pada masa Rasulullah SAW. Dapat dipahami juga bahwa mereka tidak beralasan pada benda yang dicuri semata-mata ketika melakukan hukuman potong tangan pada masa Nabi, karena tidak ditemukan hukuman potong tangan hanya karena benda yang dicuri. Jika Nabi SAW memotong tangan seorang pencuri yang mencuri benda seharga المجن, tidak berarti bahwa hukum potong tangan berlaku pada aspek itu saja. Hal ini karena sebagian dari perbuatan Nabi SAW berbentuk lafal yang umum dan beragam peristiwa pencurian yang terjadi pada masa itu. Sehingga perbuatan Nabi menjadi petunjuk (توقيف) bagi Sahabat dalam melaksanakan hukuman potong tangan dan tidak melaksanakan hukuman itu di luar petunjuknya.

Penjelasan ini menunjukkan bahwa posisi مجمل ayat ialah pada المقار harta yang dicuri seperti ditunjukkan secara lafziyah oleh banyak hadis yaitu larangan 567.

${ }^{12}$ Musa Syahîn Lashin, Fath al-Mun'im Syarh Sahîh Muslim, Jilid 7, (Kairo: Dâr al-Syurûq, 2002),

${ }^{13}$ al-Jassâs, Tafsîr..., 415. 
memotong tangan pencuri yang mencuri kurang dari harga المجن. Oleh sebab itu, tidak bisa dari segi demikian memandang keumuman ayat. Ke-mujmal-an ayat dari segi المقار tidak mesti memandangnya مجمل secara keseluruhan, karena bisa memandang keumuman ayat dari segi lain, misalnya jenis-jenis harta yang dicuri dan lain-lain. Pemahaman ini selaras dengan firman Allah SWT dalam al-Qur'an surat al-Taubah (9): 103 yaitu:

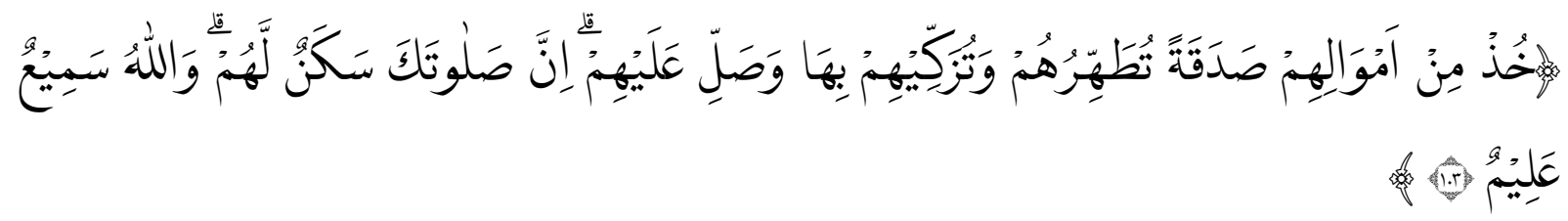

Terjemahnya :

Ambillah zakat dari harta mereka, guna membersihkan dan menyucikan mereka, dan berdoalah untuk mereka. Sesungguhnya doamu itu (menumbuhkan) ketenteraman jiwa bagi mereka. Allah Maha Mendengar, Maha Mengetahui. ${ }^{14}$

Ayat ini bersifat umum dari segi harta (الأموال) yang diwajibkan untuk dibayarkan zakatnya dan bersifat mujmal dari segi المقار harta yang diwajibkan seperti halnya lafal ayat فاقطعو آليديهما yang mewajibkan hukuman potong tangan pada setiap bentuk pencurian dan bersifat mujmal dari segi ukuran minaimal harta yang dicuri. Uي ثمن Ulama mazhab Hanafi banyak menggunakan hadis yang mencantumkan lafal sebagai dalil untuk menentukan batas minimal harta curian. Mereka tidak menggunakan hadis-hadis yang lebih sahih yang menjelaskan 1/4 dinar ukuran minimal harta yang dicuri. Di antara hadis-hadis itu adalah sebagai berikut:

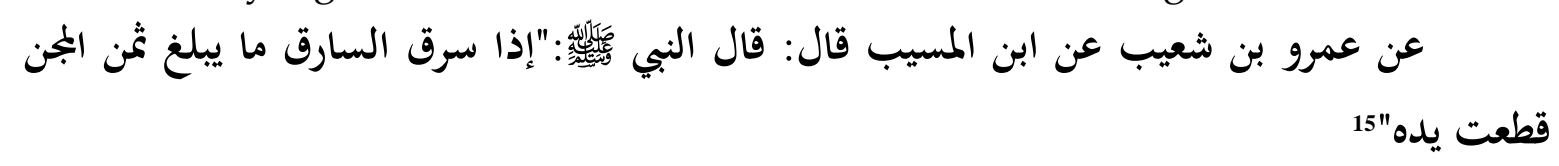

Artinya :

Hadis diriwayatkan dari Amr ibn Syu'aib dari Ibn al-Musayyab ia berkata: Nabi SAW bersabda:"Apabila seseorang mencuri yang harta curiannya mencapai harga al-mijann, maka dipotong tangannya."

Pada hadis ini tidak dijelaskan tentang nilai/harga المجن, tetapi pada hadishadis lain ditemui harga المجن yang berbeda-beda, mulai dari harga yang rendah, harga menengah dan harga yang tinggi. Hadis yang diterima dari Aiman mengatakan bahwa harga المجن ialah 1 dinar seperti berikut ini:

14 Al-Qur'ân, al-Taubah (9): 103.

15 Abu Bakr Abd al-Razzâq ibn Hammâm ibn Nâfi' al-San'âniy, al-Musannif, Jilid 9, Beirût: Dâr al-Kutub al-Ilmiah, 2000, 520. 


\section{عن مجاهد عن أيمن قال: لم يقطع اليد على عهد رسول الله صلى الله عليه و سلم إلا فى ثمن الجزن \\ وثمنه يومئذ دينار 16}

Artinya :

Hadis diriwayatkan dari Mujahid, dari Aiman ${ }^{17}$, ia berkata tidak dipotong tangan (seorang pencuri) pada masa Rasulullah SAW kecuali seharga al-mijann yang ketika itu harganya satu dinar. ${ }^{18}$

Hadis yang diterima dari Ibn Abbas mengatakan bahawa harga المجن ialah 10 dirham seperti lafal hadis berikut ini:

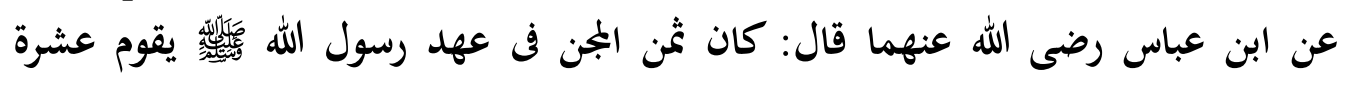

Artinya :

Hadis diriwayatkan dari Ibn Abbas r.a. ia berkata: harga mijann pada masa Rasulullah SAW bernilai 10 dirham.

Adapun hadis yang diterima dari Ibn Umar mengatakan bahwa harga المجن ialah 5 dirham seperti berikut ini:

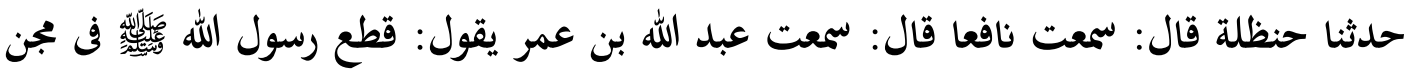

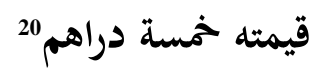

16 al-Naisaburiy, al-Mustadrak ala al-Sahîhain, Juz. 4, (Beirût: Dâr al-Kutub al-Ilmiyah, 1990), 420.

${ }^{17}$ Kedudukan Aiman sebagai sanad hadis ini diperdebatkan oleh ahli ilmu, sehingga memberi pengaruh dalam menjadikan hadis ini sebagai dalil untuk menetapkan ukuran minimal potong tangan. Imam al-Syafi'iy berkata kepada Muhammad ibn al-Hasan bahwa Sunnah Rasulullah SAW telah memerintahkan untuk memotong tangan pada pencurian 1/4 dinar atau lebih. Bagaimana mungkin bisa dikatakan tidak dipotong tangan pencuri kecuali harta curiannya mencapai sepuluh dirham atau lebih. Imam al-Shafi'iy mengatakan bahwa Aiman telah terbunuh dalam perang Hunain sebelum Mujahid dilahirkan, sehingga diperdebatkan apakah Aiman ini seorang Sahabat atau tabiin. Pada penghujung perdebatan disebutkan bahwa jika Aiman seorang Sahabat, maka hadisnya ini tidak diragukan lagi. Akan tetapi jika ia salah seorang tabiin, maka hadisnya mursal. Hadis mursal dalam pandangan ulama mazhab Hanafi dan mayoritas ulama lain tidak tercela tetapi ia bisa menjadi dalil dan patut mempertimbangkannya sebagai hujah. Lihat Muhammad Zakariya al-Kandahlawiy, Aujâz al-Masâlik ila Muwatha`Mâlik, Juz 15, (Damaskus: Dâr al-Qisâ’, 2003), 397.

18 Jika dikurskan dengan nilai mata uang sekarang, menurut Shauqiy Isma'il Shahâtah (seorang ahli fiqh dari Mesir), satu dinar tersebut ialah sama dengan 4, 457 gram mas dan dibulatkan menjadi 4,5 gram mas. Dengan demikian nisâb harta curian yang mesti dihukum dengan hukuman potong tangan menurut mayoritas ulama ialah 4,5:4=1, 125 gram mas dan menurut ulama mazhab Hanafi ialah 4,5 gram mas. Lihat Abdul Aziz Dahlan (et al.), Ensiklopedi hukum Islam, Jilid 4, (Jakarta: Ichtiar baru Van Hoeve, 1997), 1392.

19 al-Naisaburiy, al-Mustadrak..., 420. 


\section{Artinya :}

Hanzalah menceritakan bahawa ia telah mendengar Nafi' berkata bahwa Nafi' telah mendengar Ibn Umar berkata: Rasulullah SAW telah memotong (tangan pencuri) seharga mijann yang bernilai 5 dirham

Hadis yang diterima dari Ibn Umar yang lain menyebutkan bahwa harga المجن ialah 3 dirham seperti berikut ini:
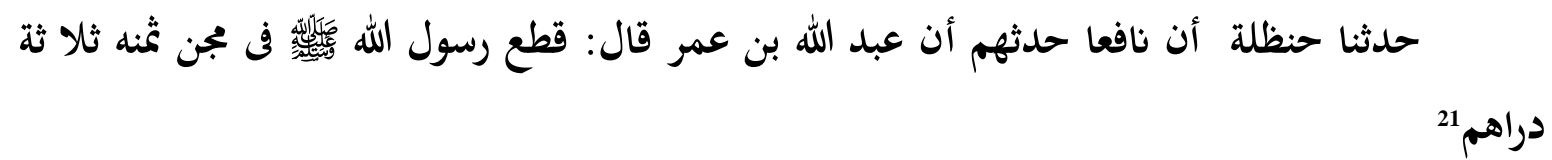

Artinya :

Hanzalah menceritakan bahwa Nafi' mengabarkan kepada mereka mengenai Ibn Umar yang berkata: Rasulullah telah memotong (tangan pencuri) seharga mijann yang bernilai 3 dirham.

Hadis-hadis di atas menjelaskan bahwa ukuran minimal potong tangan dalam pencurian ialah sama nilainya dengan harga al-mijann, sedangkan harga al-mijann berbeda-beda, baik 3 dirham, 5 dirham, maupun 10 dirham. Alasan ini didukung juga oleh keputusan Umar ibn al-Khattab yang menggugurkan hadd potong tangan dari seorang pencuri. Pada awalnya Umar memutuskan hukuman potong tangan bagi seorang pencuri yang mencuri sehelai pakaian. Kemudian Umar menilai harga pakaian curian itu dan mengatakan bahwa harganya tidak mencapai sepuluh dirham, tetapi hanya sekitar 8 dirham. Oleh sebab itu, Umar menggugurkan hukuman potong tangan dari pencuri tersebut. ${ }^{22}$ Pada kasus ini ulama mazhab Hanafi mengatakan bahwa nisâb harta curian dinilai dengan dirham (10 dirham), karena harga pakaian yang dicuri diperkirakannya hanya sekitar 8 dirham. Artinya, harta curian yang kurang dari 10 dirham dapat menggugurkan hukuman hadd, karena harga pakaian 8 dirham itu mengandung unsur ketidakjelasan (syubhat).

Terlepas dari perdebatan itu, ulama mazhab Hanafi mengambil ukuran melalui harga tertinggi al-mijann yaitu 10 dirham (الأخذ بالأثثر) sebagai batas minimal harta curian yang mengakibatkan hukuman potong tangan. Mereka mengatakan bahwa pengambilan nilai tertinggi ialah helah ${ }^{23}$ yang lebih utama untuk meniadakan

20 al-Nasâiy, Sunan al-Nasâiy, Juz 4, (Kairo: Dâr al-Hadîth, 1999), 402.

${ }^{21}$ al-Nasâiy, Sunan al-Nasāiy, 403.

22 Abu Bakr Abd al-Razzâq ibn Hammâm ibn Nafi' al-San'âniy, al-Musannif..., 521.

${ }^{23}$ Helah atau الحيلة dalam kajian ini adalah usaha ulama untuk keluar dari masalah yang belum (tidak bisa) dituntaskan karena adanya berbagai keterbatasan. Konsep الحيلة banyak dibicarakan dalam mazhab Hanafi. الحيلة atau jamaknya الحيل ialah kecerdikan, tipu daya, muslihat, siasat dan alasan yang dicari-cari untuk keluar (melepaskan diri) dari suatu perbuatan yang pada lahirnya dibenarkan untuk membatalkan hukum syarak lainnya. Lihat Mannâ' al-Qattân, Tarîkh al-Tasyrî́ al-Islâmiy, (Riyâdh: Maktabah al-Ma'ârif, 1992), 333. Berdasarkan pengertian dasar الحيلة tersebut, mayoritas ulama lebih cenderung untuk tidak membenarkan penggunaannya sebagai dalil, karena di dalamnya 
hukuman hadd (أن الأخذ بالأكثر فى هذا الباب أولى احتيالا لارع الدا). Jika diambil nilai terendah dalam menetapkan ukuran minimal harta curian, bisa menjerumuskan pada wilayah (syubhat), karena dipandang tidak terjadi jinayah dalam pencurian harta yang nilainya rendah dan tabiat manusia tidak cenderung pada harta yang bernilai rendah. Dengan demikian, syariat tidak menetapkan hukuman untuk pencurian apakah nilainya rendah ataupun tiada nilai sama sekali, sedangkan syubhat ialah di antara aspek yang dapat menggugurkan hukuman hadd. ${ }^{24}$

Pertimbangan mazhab Hanafi dalam mengambil keputusan nilai 10 dirham sebagai عشرة دراهم وزن سبعة karena 10 dirham masuk dalam kategori wazan yang tujuh atau ukuran standar. Mereka mengatakan bahwa penamaan الدراهم secara mutlak berlaku demikian. Dalam ketentuan zakat dan diyat dijumpai bahwa keduanya diukur menggunakan dirham dan tidak diukur dengan menggunakan dinar. Misalnya, kewajiban zakat pada harta benda selain hewan peliharaan dan hasil pertanian dihitung berdasarkan mata uang dirham. Di antaranya hadis Rasulullah SAW yang berbunyi:

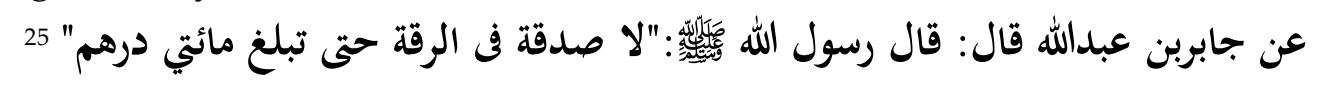

Artinya :

Hadis diriwayatkan dari Jabir ibn Abdillah dia berkata: Rasulullah SAW berabda:"Tiada kewajiban zakat pada budak sehingga mencapai harga 200 dirham."

Hadis ini menjelaskan bahwa zakat harta seperti zakat budak dihitung dengan menggunakan mata uang dirham. Selain itu, Nabi SAW memberi nafkah isteri-isterinya dengan menggunakan mata uang dirham ${ }^{26}$ dan masyarakat pada

mengandung maksud menghindarkan diri dari hukum syarak. Berdasarkan kaidah umum bahwa pada dasarnya setiap perbuatan dibolehkan sampai ada dalil yang menjelaskan kedudukan halal ataupun halalnya tetapi jika perbuatan yang dibolehkan itu dapat membatalkan hukum syarak yang telah ada, maka perbuatan seperti itu tidak dibenarkan. Al-Shâtibiy membagi الحيلة pada tiga bagian yaitu: (1) helah yang disepakati ulama untuk tidak membolehkannya seperti helah yang dilakukan oleh orang-orang munafik. (2) Helah yang disepakati oleh ulama untuk membenarkannya seperti mengucapkan kalimat kekafiran dalam keadaan terpaksa. (3) Helah yang diperdebatkan oleh ulama tentang kebolehannya. Jenis ketiga ini berada pada masalah-masalah yang meragukan, misalnya aspek dalam nikah tahlil yang mempunyai helah untuk rujuk kepada isteri yang telah ditalak tiga dan masalah ukuran minimal nisab harta curian. Lihat al-Syâtibiy, al-Muwâfaqât fi Usûl al-Ahkâm, Jilid 2, (Beirût: Dâr al-Fikr, t.th), 270-271. $342 \& 343$.

${ }^{24}$ Ibn al-Humâm al-Hanafiy, Syarh Fath al-Qadîr, Juz 5, (Beirût: Dâr al-Kutub al-Ilmiyah, 1995),

\footnotetext{
25 al-Baihaqqiy, Sunan..., 226.

${ }^{26}$ al-Baihaqqiy, Sunan..., 226.
} 
masa itu menggunakan dirham sebagai nilai tukar, karena ia (dirham) dipandang sebagai mata uang yang paling sesuai (أوسط المقادر), memiliki nilai besar dan kecil yang telah digunakan dan dipakai sejak masa Nabi SAW. Jika digabung nilai besar dan nilai kecil mata uang tersebut, maka ia menjadi dua nilai dirham yang masuk sebagai bagian dari السبعة wazan/setimbangan yang paling sesuai dan selaras dengan hadis yang mengatakan خيرالأمورأوسطها (sebaik-baik perkara ialah yang pertengahan) ${ }^{28}$ dan خيرالأعمال أوسطها (sebaikbaik perbuatan ialah yang pertengahan). ${ }^{29}$ Abu Hanifah sendiri juga menjadikan alasan hadis yang mengatakan bahwa ukuran minimal potong tangan ialah 10 dirham seperti berikut ini:

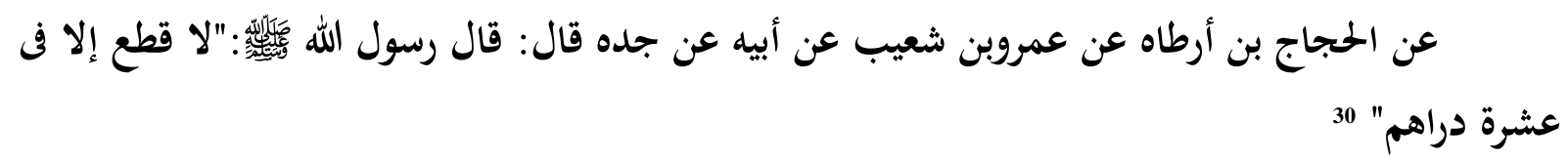

\section{Artinya :}

Hadis diriwayatkan dari al-Hujjaj ibn Artah dari Amr ibn Syu'aib dari ayahnya dari kakeknya ia berkata: Rasulullah SAW bersabda:"Tidak ada hukuman potong tangan kecuali dalam ukuran 10 dirham."

Berdasarkan hadis ini, Nabi SAW meniadakan hukuman potong tangan pada pencurian yang kurang dari 10 dirham, baik jumlah itu kurang dari, sama dengan, atau lebih dari $1 / 4$ dinar. ${ }^{31}$ Selain itu, Abu Hanifah juga berdalil kepada hadis lain yaitu:

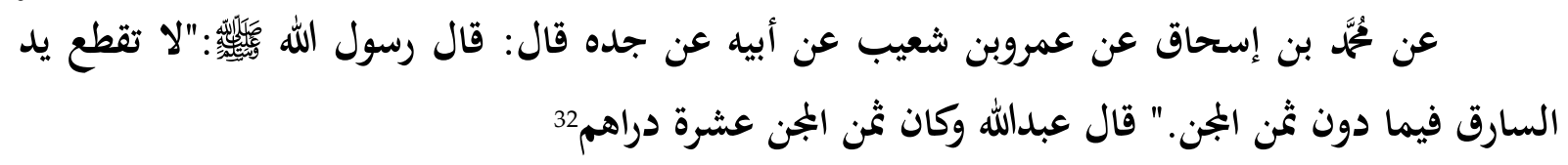

27 Ibn Mas'ûd al-Kasâniy, Badâi' al-Sanâi' fi Tartîb al-Syarâi', Juz. 9, (Beirût: Dâr al-Kutub alIlmiyah, 1997), 320.

28 al-Qurtubiyy, al-Jâmi' al-Ahkâm al-Qur'ân, Juz 2, (Beirût: Dâr al-Kâtib al-Arabiy, 1967), 154.

${ }^{29}$ al-Muttaqa al-Hindiy al-Burhân Fauriy, Kanz al-'Ummâl fi Sunan al-Aqwâl wa al-Af́âl, Juz 10, (Beirût: Muassasah al-Risâlah, 1989),132.

${ }^{30}$ Ahmad Ibn Hanbal, Musnad al-Imâm Ahmad Ibn Hanbal, Juz 2, (Beirût: al-Maktab al-Islâmiy, 1993), 269.

31 Pendapat ulama mazhab Hanafi ini dibantah oleh ulama mazhab Syafi'iy. Mereka mengatakan bahwa salah seorang dari sanad hadis yaitu الحجاج بن أرطاه tidak dikenal (مدلس) dan hadis ini tidak didengar dari عمروبن شعيب. Dengan demikian hadis ini tidak bisa dijadikan sebagai dalil untuk mendukung pendapat tentang ukuran minimal hukuman potong tangan. Lihat Abi Muhammad alHusain Ibn Masud Ibn Muhammad Ibn al-Farrâ', al-Tahzîb fi Figh al-Imâm al-Syâfi'iy, Jilid 7, (Beirût: Dâr al-Kutub al-Ilmiyah, 1997), 358.

32 Muhammad Ibn Abi Shaibah, al-Musannif fi al-Ahâdith wa al-Atsâr. Beirût: Dâr al-Fikr, 1989, 465. 


\section{Artinya :}

Hadis diriwayatkan dari Muhammad ibn Ishaq dari Amr ibn Syuaib dari ayahnya dari kakeknya ia berkata: Rasulullah SAW bersabda:"Tidak dipotong tangan seorang pencuri yang mencuri kurang dari harga al-mijann." Abdullah berkata harga al-mijann ialah 10 dirham.

Pada hadis ini Nabi SAW melarang untuk melakukan hukuman potong tangan pada pencurian yang nilainya kurang dari 10 dirham (seperti dijelaskan dalam hadis bahwa harga al-mijann pada masa itu ialah 10 dirham) dengan meniadakan hukuman potong tangan yang harta curiannya kurang dari harga almijann. ${ }^{33}$ Hadis ini sarîh yang menjelaskan bahwa harta benda (العروض) selain mas dan perak dinilai dengan dirham dengan tidak membandingkannya dengan harga dinar mas, karena mata uang dirham digunakan untuk menilai المجن. Di sisi lain المجن itu sendiri ialah salah satu dari jenis العروض (harta benda selain mas dan perak). Pada gilirannya, ulama mazhab Hanafi berpegang pada nilai 10 dirham sebagai ukuran minimal kewajiban memotong tangan pencuri. Mereka membandingkan dan berdalil pada mata uang dirham yang lebih banyak digunakan dalam masalah-masalah syariat yang lain. Artinya mereka menggunakan dalil-dalil akal yang tidak lepas dari bimbingan wahyu.

Dalam kehidupan modern, ditemukan beberapa negara Islam yang menggunakan pendapat ulama Mazhab Hanafi tentang nisâb harta curian. Misalnya Pakistan yang menetapkan nisâb harta curian dalam peraturan perundangan Enforcement of Hudood Ordinance, 1979 (VI of 1979). Dalam peraturan ini disebutkan bahwa the nisâb for theft liable to hadd is four decimal four five seven $(4,457)$ grams of gold or other property of equivalent value, at the time of theft. ${ }^{34}$ Nilai 4,457 gram emas ini sama dengan 1 (satu) dinar atau 10 dirham menurut ulama mazhab Hanafi. Selain Pakistan, Syi'ah modern di Iran juga menggunakan nilai 10 dirham sebagai nisâb atau batas minimal harta curian untuk hukuman potong tangan. ${ }^{35}$

33 Pandangan ulama mazhab Hanafi ini dibantah oleh ulama mazhab Syafi'iy. Mereka mengatakan bahwa hadis ini tidak bisa dijadikan sebagai dalil, karena di antara sanadnya terdapat nama عنعن yang mempunyai banyak. Oleh sebab itu, sekiranya datang sebuah hadis yang mempunyai banyak (معنع), maka hadis tersebut tidak bisa menentang (لمعارضة) hadis Aisyah yang menjelaskan ukuran nilai المجن sebanyak 1/4 dinar dan hadis Ibn Umar yang menjelaskan masalah yang sama yaitu harga المجن senilai 3 dirham yang sama dengan 1/4 dinar. Sekiranya boleh untuk menta'ârud-kan hadis tersebut, maka si perawi محدبن إسحاق mesti dibuang karena menyalahi riwayat-riwayat yang telah berlalu tentang nilai المجن, karena tidak ada satupun masalah yang mengangkat atau menghilangkan ta'ârud ini. Lihat Abi Muhammad al-Husain Ibn Mas'ud Ibn Muhammad Ibn alFarrâ', al-Tahzîb..., 358.

34 M.Mahmood, Enforcement of Hudood Practice and Procedure, (Lahore: Pakistan Law Times Publications, 1984), 464

35 Tahir Mahmood, Criminal Law in Islam and the Muslim World A Comparative Perspective, (Jamia Nagar Delhi: Qazi Publishers, 1996), 208 


\section{RESISTENSI NISÂB HARTA CURIAN MENURUT MAYORITAS AHLI FIQH}

Mayoritas ahli fiqh selain dari ulama mazhab Hanafi mempunyai pendapat yang berbeda tentang nilai minimal nisâb harta curian. Ulama mazhab Hanafi dalam pendapatnya mengambil nilai tertinggi untuk menetapkan nilai minimal harta curian, sedangkan ulama selain dari mereka mengambil nilai terendah seperti ulama mazhab Maliki, Syafi'iy, dan Hanbali. Walaupun mayoritas ulama ini mengambil nilai terendah dalam menetapkan nilai minimal nisâb harta curian, tetapi mereka juga berbeda dalam menentukan nilai tukar yang digunakan, baik dinar maupun dirham. Ulama mazhab Maliki mengatakan bahwa ukuran minimal harta curian ialah: 1). Tiga dirham atau senilai dengan tiga dirham jika harta curiannya ialah mas. 2). Harta curiannya sama dengan tiga dirham atau $1 / 4$ dinar atau harganya senilai dengan keduanya. 3). Harta benda selain mas dan perak dinilai dengan dirham. ${ }^{36}$ Imam Malik mengatakan bahwa harta benda selain mas dan perak dinilai dengan dirham perak dan tidak dengan $1 / 4$ dinar mas yaitu jika berbeda tiga dirham dengan $1 / 4$ dinar, karena berbedanya nilai tukar. Misalnya nilai tukar $1 / 4$ dinar emas sama dengan 2,5 dirham perak. ${ }^{37}$

Berdasarkan ukuran yang ditetapkan ini, maka siapa saja yang mencuri emas yang timbangannya (وزنه) 1/4 dinar, dipotong tangannya walaupun harga (قيمته) satu dirham saja. Jika nilai tukarnya tidak mencapai $1 / 4$ dinar, tidak dipotong tangannya sekalipun harganya sama dengan tiga dirham atau lebih. Demikian juga seseorang yang mencuri perak, maka yang diperhitungkan ialah وزنه bukan قيمة dari harga emas. Akan tetapi khusus untuk harta benda selain mas dan perak, maka harta curian itu قيمته tiga dirham akan dipotong tangan sekalipun tidak sama dengan emas 1/4 dinar. Sekiranya sama dengan $1 / 4$ dinar dan tidak sama dengan tiga dirham, tidak dipotong tangannya. Hanya saja dinilai segala sesuatu benda selain emas dan perak dengan dirham. ${ }^{38}$ Mereka beralasan kepada hadis yang diriwayatkan oleh Ibn Umar sebagai berikut:
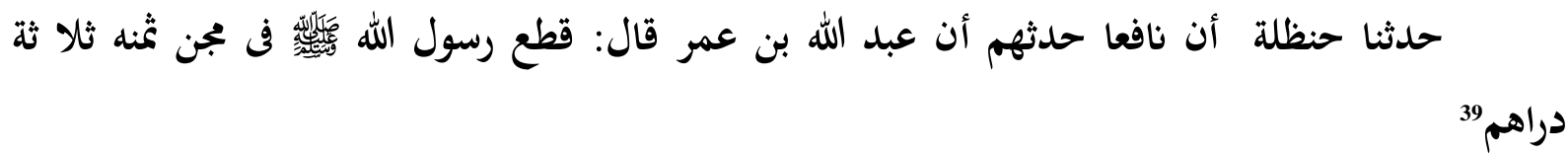

Artinya :

Hanzalah menceritakan bahwa Nafi' mengabarkan kepada mereka tentang

${ }^{36}$ Ibn Qudâmah, al-Mughniy, Jilid 26, (Riyâd: Dâr al-' Ălim Kutub, 1998), 488 \& 489.

37 Ibn Rusyd, Bidâyat al-Mujtahid wa Nihâyat al-Muqtasid, Jilid 2, (Beirût: Dâr al-Kutub alIlmiyah, 1997), $655 \& 656$.

38 Abi Sa'id al-Barâziy, al-Tahzîlb fi Ikhtisâr al-Mudawwanah, (Dubai: Dâr al-Buhûth li al-Dirâsât al-Islâmiyah, 2002), 425.

${ }^{39}$ al-Nasâiy, Sunan..., 403. 
Ibn Umar yang berkata: Rasulullah telah memotong (tangan pencuri) seharga mijann yang bernilai 3 dirham.

Hadis ini menjelaskan bahwa Rasulullah SAW memotong tangan pencuri yang harta curiannya senilai dengan harga المجن yaitu tiga dirham. Ulama mazhab Syafi'iy dan Hanbali mengatakan bahawa nisab ialah syarat untuk dapat dilaksanakannya hukuman potong tangan yaitu sebanyak $1 / 4$ dinar atau benda yang senilai dengan harga $1 / 4$ dinar..$^{40}$ Mereka beralasan pada banyak hadis yang sebagian besarnya diriwayatkan oleh Aisyah, di antaranya sebagai berikut:

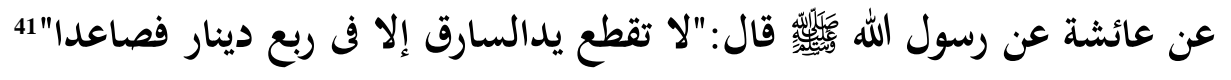

Artinya :

Hadis diriwayatkan dari Aisyah dari Rasulullah SAW beliau bersabda:"Tidak dipotong tangan pencuri kecuali (harta curiannya) mencapai $1 / 4$ dinar atau lebih."

Hadis ini menjelaskan bahwa ukuran minimal harta curian ialah $1 / 4$ dinar. Jika seseorang mencuri selain emas, maka benda itu wajib dinilai dengan emas (الذهب), karena Nabi SAW menetapkan nisâb harta curian dengan mas. Hadis lain yang digunakan oleh ulama mazhab Syafi'iy dan ulama mazhab Hanbali ialah sebagai berikut:

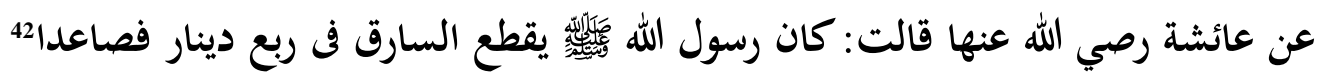

Artinya :

Hadis diriwayatkan dari Aisyah ia berkata: Rasulullah SAW telah memotong (tangan) seorang pencuri pada $1 / 4$ dinar atau lebih.

Sebagaimana hadis sebelum ini, dalam hadis di atas Rasulullah SAW juga telah melaksanakan hukuman potong tangan pada pencurian 1/4 dinar atau lebih. Selain dua hadis di atas, banyak lagi hadis lain yang menjelaskan hukuman potong tangan pada curian 1/4 dinar atau lebih. Hadis-hadis ini ialah sarîh untuk menjadi ukuran nisâb sebagai syarat wajib potong tangan. Selain itu, para Sahabat menyepakati bahwa nisâb ialah syarat untuk pelaksanaan hukuman potong tangan, sekalipun mereka berbeda pendapat dalam jumlahnya.

Hadis-hadis di atas ialah hadis yang bersifat khabar tentang perbuatan Rasulullah yang memotong tangan pencuri pada $1 / 4$ dinar, sedangkan pada hadis lain Nabi SAW memerintahkan untuk melaksanakannya seperti hadis berikut ini:

\footnotetext{
${ }^{40}$ Muhammad Najib al-Mutî̀iy, Kitâb..., 4.

41 'Iyâd Ibn Musa Ibn 'Iyad, Syarh Sahîh Muslim li al-Qâdi 'Iyad al-Musamma Ikmâl al-Mu'lim bi Fawâid Muslim, Juz 5, (Beirût: Dâr al-Wafâ', 1998), 495 \& 496.

42 Mûsa Shahîn Lashîn, Fath..., 563.
} 


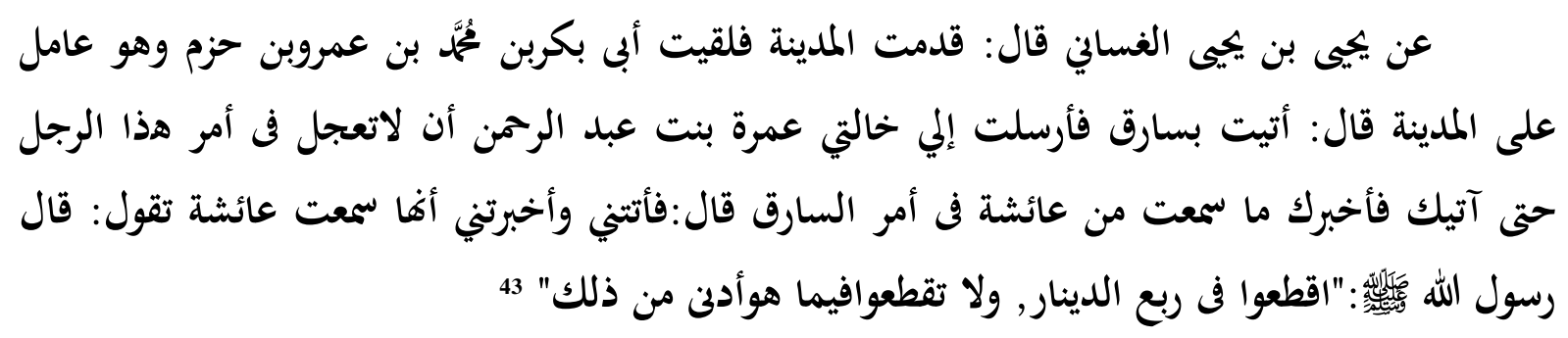

Hadis diterima dari Yahya ibn Yahya al-Ghassaniy ia berkata: Aku memasuki Madinah dan aku berjumpa dengan Abi Bakr ibn Muhammad ibn Amr ibn Hazm dan dia ialah seorang amil di Madinah, dia berkata: Didatangkan kepadaku seorang pencuri, maka aku mengirimnya kepada bibiku Amrah binti Abd al-Rahman bahwa ia tidak melalaikan urusan lelaki ini sehingga aku (Yahya) datang kepada engkau dan mengabarkan kepadamu tentang apa yang aku dengar dari Aisyah tentang seorang yang mencuri, maka ia berkata: Kemudian Amrah mendatangiku dan mengkhabarkan kepadaku bahwa ia mendengar Aisyah berkata: Rasulullah SAW bersabda:"Potonglah olehmu pada 1/4 dinar dan janganlah engkau memotong pada pencurian benda yang kurang dari itu."

Pada hadis ini, Rasulullah SAW memerintahkan untuk melaksanakan hukuman potong tangan pada pencurian $1 / 4$ dinar dan melarang untuk memotong tangan pada pencurian kurang dari $1 / 4$ dinar. Imam Syafi'iy mengatakan bahwa nisâb harta curian ialah $1 / 4$ dinar, seperti dikemukakan dalam hadis-hadis di atas, karena itulah asal penilaian emas murni, sehingga seseorang yang mencuri dirham atau selain dari dirham selalu dinilai dengan dinar. Dinar yang muktabar (terkenal) nilainya ialah 1/4 dinar ketika harta itu dikeluarkan dari tempatnya. ${ }^{44}$ Berdasarkan penjelasan ini dapat dipahami bahwa mayoritas ulama selain ulama mazhab Hanafi mengambil nilai terendah nisâb (الأخذ بالأقلّ) untuk menetapkan hukuman potong tangan yaitu tiga dirham menurut ulama mazhab Maliki dan 1/4 dinar menurut ulama mazhab Shafi'iy dan Hanbali. ${ }^{45}$ Keputusan mayoritas ulama selain ulama mazhab Hanafi untuk mengambil nilai terendah (الأخذ بالأقل) sebagai ukuran minimal potong tangan ialah dengan pertimbangan bahwa mengambil nilai terendah ialah karena lebih utama berkeyakinan dengannya (وهو المتيقن به أولىى).

Mayoritas ulama mengatakan bahwa wajib beramal dengan hadis-hadis yang diriwayatkan dari Aisyah tentang hukuman potong tangan pada pencurian 1/4 dinar atau lebih dan bukan pada pencurian 10 dirham. Pendapat ini lebih kuat dan lebih membawa ketentraman dan ketenangan jiwa, karena dalil-dalilnya lebih kuat dan

${ }^{43}$ Ahmad Ibn Hanbal, al-Musnad..., 94.

44 Muhammad ibn Idris al-Syâfi'iy, al-Risâlah, (Mesir: Mustafa al-Bâby al-Halabiy, 1940), 425.

${ }^{45}$ Muhammad Zakariya al-Kandahlawiy, Aujâz..., 397. Lihat juga Ibn Qudâmah, al-Mugniy wa al-Syarh al-Kabîr 'ala Matan al-Qâni' fi al-Figh al-Imâm Ahmad ibn Hanbal, Jilid 10, (Beirût: Dâr al-Fikr, 1983), 235, 236, \& 237. 
lemahnya dalil-dalil yang membantah. Selain itu, ulama mazhab Syafi'iy berdalil kepada perbedaan kurs peredaran mata uang dinar dan dirham. Mata uang perak (الفضة) berbeda harga/nilainya dengan terjadinya perbedaan zaman dan peredarannya. Adapun mata uang mas (الذهب) pada dasarnya mempunyai nilai yang stabil di seluruh dunia. Menurut kebiasaannya nilai emas tidak berubah (secara signifikan) seperti halnya dirham dengan berubahnya zaman dan peredarannya. Oleh karena itu, tidak ada keraguan bahwa ukuran nisâb harta curian itu telah pasti dan menjadi satu sebab yang sama pada zaman, masa, dan peredaran uang yang berbeda-beda. Pendapat ini yang lebih dekat pada keadilan dan persamaan. ${ }^{46}$ Pada dasarnya hadis-hadis tentang في ريع dan في المن المجن dapat digunakan keduanya, karena dalam hadis lain dijelaskan bahwa tiga dirham sama dengan 1/4 dinar. Berdasarkan hal ini, Imam al-Syafi'iy mengatakan bahwa harga satu dinar pada masa Rasululah SAW ialah sama dengan 12 dirham, maka tiga dirham ialah sama dengan $1 / 4$ dinar.

Sudan adalah salah satu negara Islam yang menerapkan pendapat ulama di atas dalam aturan perundangan mereka yaitu Penal Code (September 8, 1983) Sec. 320(b). Dalam peraturan ini disebutkan bahwa a quarter of a golden dinar or three dirhams of silver or its equivalent worth in Sudanese currency. Demikian juga di Saudi Arabia yang disebut para peneliti sebagai negara almost a crime-free country, di Yaman yang diatur dalam A Comprehensive Criminal Procedure Code tahun 1979 dan di Libya yang diatur dalam A New Law on Offences Against Property tahun 1973. ${ }^{47}$

\section{RESISTENSI NISAB HARTA CURIAN MENURUT ULAMA MAZHAB ZAHIRI}

Kalangan ulama mazhab Zahiri mengatakan النصاب dan dukan syarat untuk pelaksanaan hukuman potong tangan.48 Mereka berdalil pada umum ayat al-Qur'an surah al-Maidah (5): 38. Pada ayat, ini Allah SWT menyertakan السرقة setelah. Perbuatan mencuri ini menjadi illah (sifat nyata dan terukur) yang menyebabkan mesti dilaksanakan hukuman potong tangan dengan tidak membeda-bedakan antara pencurian sedikit harta dengan pencurian harta dalam jumlah banyak. Ini karena nama mencuri terpakai pada perbuatan mencuri, baik sedikit maupun pencurian dalam jumlah besar. Selain itu, mereka berdalil pada hadis-hadis Rasulullah SAW, di antaranya sebagai berikut:

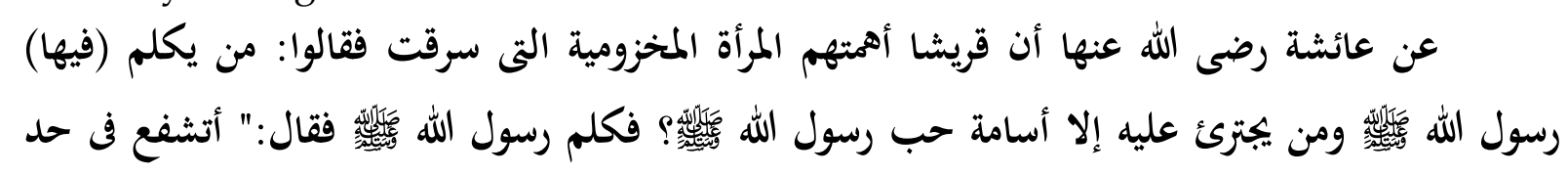

\footnotetext{
46 Abi Muhammad al-Husain Ibn Mas'ud Ibn Muhammad Ibn al-Farrâ', al-Tahzîb..., 358.

47 Tahir Mahmood, Criminal..., 209

${ }^{48}$ Ibn Hazm, al-Muhalla, Juz 11, (Beirût: al-Maktab al-Tijâriy, t.th), 326, 327 dan 351.
} 


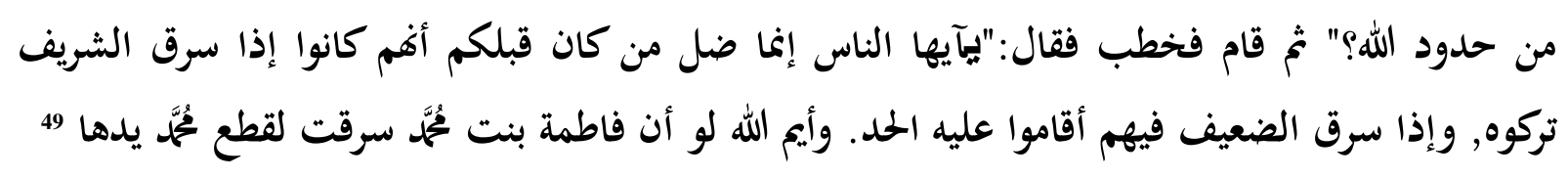

Artinya :

Hadis diriwayatkan dari Aisyah r.a. bahwa beberapa orang dari suku Quraisy bermaksud menolong seorang perempuan dari kalangan bani Makhzum yang telah mencuri. Mereka berdiskusi tentang siapa yang akan berbicara tentang perempuan ini kepada Rasulullah SAW yaitu orang yang meminta keringanan kepadanya selain daripada Usamah? Maka dia membicarakan hal itu kepada Rasulullah SAW. Rasulullah SAW bersabda:"Apakah engkau meminta pengampunan dari salah satu hukumanhukuman hudud?" Kemudian Rasulullah SAW berdiri dan berkhutbah dengan mengatakan:"Wahai sekalian manusia, sesungguhnya telah celaka orang-orang sebelum kamu, jika mencuri seseorang dari kalangan bangsawan, mereka membiarkannya dan jika mencuri seseorang dari kalangan rakyat biasa, maka mereka melaksanakan hukuman hadd kepadanya. Demi Allah, sekiranya Fatimah binti Muhammad yang mencuri, niscaya Muhammad akan memotong tangannya."

Adapun hadis-hadis yang menunjukkan ukuran nisâb ialah hadis-hadis ahâd yang bernilai zanniy, karena ukuran minimal yang dijelaskan oleh masing-masing hadis tersebut berbeda. Oleh sebab itu, tidak tepat jika hadis-hadis itu men-takhsîs (membatasi) keumuman ayat. ${ }^{50}$ Pemikiran ulama mazhab Zahiri ini dibantah oleh ulama mazhab Syafi'iy. Mereka mengatakan bahwa العام berbeda dilâlah-nya, baik ظنية ataupun قطعية. Perbedaan ini tidak perlu diperdebatkan, karena ahli-ahli ilmu yang berpendapat dari segi ظنية mengatakan bahwa hadis-hadis ini bisa men-takhsîs keumuman ayat karena kedua-duanya (ayat dan hadis) sama-sama ظني الدلالة. Sementara itu, ahli ilmu yang berpendapat dari segi قطعية mengatakan bahwa hadishadis ini ialah متواترة معنى, karena ditemukan dalam banyak periwayatan, sehingga hadis-hadis itu menjadi قطعي الدلالة dalam makna yang berbeda-beda yaitu ukuran nisâbnya. Jadi, hadis-hadis tentang قي ريع دينار ini bisa men-takhsîs keumuman surat alMaidah ayat $38 .{ }^{51}$ Selain hadis di atas, kalangan ulama mazhab Zahiri juga berdalil kepada hadis Rasulullah SAW sebagai berikut:

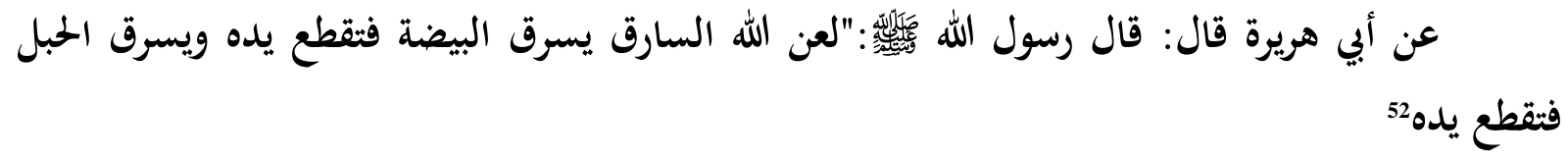
1999), 346.

${ }^{49}$ Ibn Hajr al-Asqalâniy, Fath al-Bâriy Syarh Sahîh al-Bukhâriy. Jilid 15, (Kairo: Dâr al-Manâr,

50 Ibn Hazm, al-Muhalla..., 351.

${ }^{51}$ Muhammad Ibn al-Farrâ', al-Tahzîb..., 355.

${ }^{52}$ Muslim, Sahîh Muslim máa Syarhihi al-Musamma Ikmâl al-Mu'allim, Juz 6, (Beirût: Dâr al- 
Artinya :

Hadis diriwayatkan dari Abi Hurairah ia berkata: Rasulullah SAW telah bersabda:"Allah melaknat pencuri yang mencuri telur dan pencuri yang mencuri tali, maka dipotong tangannya."

Pada hadis ini Rasulullah SAW menyertakan القطع dan البيضة da pancurian الحبل. Telah dipahami bahwa telur dan tali tidak sama dengan uang. Oleh karena itu, potong tangan berlaku pada pencurian, baik dalam jumlah yang sedikit maupun dalam jumlah yang banyak. Perawi hadis ini (الأعمش) menyatakan bahwa yang dimaksud dengan بيضة العديد ialah البيضة sedangkan yang dimaksud dengan الحبل ialah حبنة السفينة. Pada hakikatnya tidak perlu berlindung pada takwil ini, karena hadis ini dikeluarkan untuk mengecam seorang pencuri, terlebih dengan besarnya kerugian dan penderitaan yang mereka peroleh setelahnya. Jika tidak dipotong tangan pencuri pada pencurian telur, yang kebiasaan memotong tangan itu berlaku pada pencurian yang mencapai nisâb atau lebih, maka diibaratkan bahwa sebiji telur tetap dipandang bernilai. Penafsiran hadis kepada بيضة الحديد keluar dari pembicaraan yang bermakna, karena بيضة الحديد telah terukur harganya yaitu melebihi ukuran nisâb harta curian. Oleh karena itu, menurut kebiasaan, tidak keluar celaan dari sesuatu benda yang nilainya besar, sehingga hadis ini keluar dari kategori sedikit ataupun banyak. ${ }^{53}$

Hadis ini juga mengandung perkataan اللعن اللعن Perkataan salah satu di antara perkataan yang mengandung pemahaman الحرمة. Perkataan اللعن dalam hadis ini ditafsirkan dalam beberapa makna seperti dinyatakan oleh Ibnu Hajr berikut ini: ${ }^{54}$ Berita atau khabar untuk mencegah atau untuk menghalang orang yang mendengarnya dari mencuri. Doa. Tidak dimaksud dari perkataan itu hakikat اللعن yang sebenarnya tetapi untuk menakut-nakuti saja. Menurut الطيبي seperti yang dikemukakan oleh Ibn Hajar bahwa yang dimaksud اللعن di sini ialah penghinaan dan pengabaian. Menurut Qadi Iyad seperti yang dikemukakan oleh Ibn Hajar bahwa bisa melaknat sesuatu hal yang belum dihukum dengan hukuman hadd, karena hadd ialah kaffârah (penebus dosa). Qadi Iyad menambahkan, perkataan ini bukanlah sekeras-kerasnya posisi larangan dari makna اللعن yang sebenarnya. Dikatakan pula bahwa Nabi SAW melaknat orang-orang yang berbuat maksiat sebagai peringatan kepada mereka untuk tidak melakukannya.

Ulama mazhab Syafi'iy mengemukakan pendapat yang berbeda. Mereka mengatakan, maksud بيضة الحيد ialah بيضة yaitu benda yang digunakan sebagai senjata (kepala/ujung senjata) dalam peperangan. Tidak ada keraguan bahwa benda itu bernilai. Adapun maksud الحبل ialah حبل السفينة yang harganya 3 dirham atau lebih. Hal

Kutub al-Ilmiyah, 1994), $152 \& 153$.

${ }^{53}$ Muslim, Sahîh..., 152 \& 153.

54 Ibn Hajar al-Asqalâniy, Fath..., 337. 
itu ditunjukkan oleh perkataan الأعمش sebagai perawi hadis. Hukuman potong tangan bagi pencuri telur sepertinya jauh dari sikap berhati-hati yang berkaitan, baik dengan jumlah sedikit ataupun banyak. Seperti penghargaan pada jumlah sedikit atau banyak dalam hadis berikut ini:

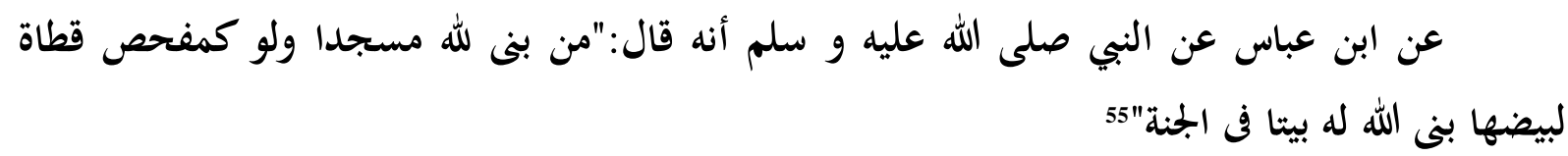

Artinya :

Hadis diriwayatkan dari Ibn 'Abbas dari Nabi SAW beliau bersabda:"Siapa yang membangun mesjid sekalipun sebesar sarang tempat burung bertelur, sungguh Allah akan membangun sebuah rumah untuknya di surga."

Hadis ini menjelaskan tentang besarnya dorongan pada orang yang membangun mesjid dengan tidak mengukur besar perbandingannya. Demikian juga posisi berhati-hati dalam kasus pencurian dan tingginya usaha pengajaran. Hal ini menghendaki turunnya nas yang menjelaskan pencurian yang tidak dipotong padanya sebagai pembanding nas yang menjelaskan pencurian yang dipotong padanya. Oleh karena itu, hadis itu tidak menjadi dalil mengenai kemestian potong tangan pada pencurian dalam jumlah yang sedikit. ${ }^{56}$

Pada dasarnya baik ulama mazhab Syafi'iy maupun mazhab Zahiri samasama melakukan penafsiran pada hadis ini. Penafsiran pertama, sekalipun mungkin dilakukan tetapi berseberangan dengan uslub bahasa Arab. Pada aspek pengajaran, menghendaki kehati-hatian dari jumlah sedikit untuk sampai pada jumlah yang banyak. Tidak sikap berhati-hati pada jumlah yang banyak dengan memberikan pemahaman bahwa tidak mengapa atau tidak apa-apa pada jumlah yang sedikit (لاالتحذيرمن الكثير المفهم أن لاحرج فى القليل). Selain itu, ungkapan seperti ini tidak muncul di kalangan orang Arab.

Segala sesuatu yang sejenis dengan hal ini ialah lebih tinggi aspek pengajarannya dan lebih bernilai sikap kehati-hatiannya. Sama juga dengan hukuman pencurian dalam jumlah sedikit atau banyak. Jika mencuri suatu benda yang tidak bernilai dalam pandangan umum seperti telur burung, tetapi ia bisa menjadi bernilai dalam jumlah banyak atau tali lapuk yang sudah disambungsambung menjadi satu karya seni, maka jenis pencurian seperti ini dapat diangkat pada pencurian yang dihukum dengan hukuman potong tangan ketika nilai bendabenda yang dicuri ini bisa membuatnya dihukum potong tangan. Seolah-olah Nabi SAW mengatakan:"Hendaklah kamu memberi peringatan kepada pencuri-pencuri 483.

\footnotetext{
55 Ahmad ibn Hanbal, al-Musnad..., Juz. 1,. 300.

56 Ibn Hayyan, Tafsîr al-Bahr al-Muhît, Jilid 3, (Riyâd: Maktabah al-Nasr al-Hadîthah, t.th),
} 
kecil sebelum menjadi kebiasaan", ${ }^{57}$ kemudian berujung pada pencurian dalam jumlah besar dan untuk menyelamatkan mereka dari hukuman (potong tangan) yang berat.

Seluruh penafsiran hadis ini tidak menjadi dalil tentang ketiadaan memandang nisâb sebagai syarat wajib potong tangan. Pendapat yang paling kuat ialah pendapat jumhur yang memandang nisâb sebagai syarat wajib potong tangan, karena kuatnya dalil-dalil yang mereka kemukakan dan lemahnya dalil-dalil kalangan lain. Hukuman potong tangan ialah hukuman yang sangat berat secara zatnya. Dengan demikian, tidak patut menjadikannya sebagai hukuman hingga harta yang dicuri ialah benda yang benar-benar cenderung jiwa kepadanya, ${ }^{58}$ dan bukan benda yang orang bermurah hati memandangnya. Benda yang sedikit/tidak bernilai tidak termasuk pada hal demikian, karena jiwa manusia pada kebiasaannya tidak cenderung kepadanya.

Menurut pandangan al-Hasan al-Basriy penilaian terhadap benda berharga tidak tergantung pada jumlahnya (banyak ataupun sedikit). Menurutnya, dipotong tangan pencuri yang mencuri benda bernilai/berharga sekalipun kuantitasnya sedikit. Ia berdalil pada keumuman surat al-Maidah (5): 38 (والسارق والسارقة فاقطعوآيديهما), karena seorang pencuri yang mengambil harta orang lain dari tempat yang

${ }^{57}$ Peringatan Nabi SAW ini di antaranya dibuktikan oleh hasil penelitian Cesare Lombroso. Dia adalah salah seorang Profesor dalam bidang psychiatry dan criminal anthropology pada University of Turin. Buku Crime Its Causes and Remedies ialah salah satu bukunya yang sangat terkenal. Buku ini mengemukakan teori bahwa the crime is caused almost entirely by the anthropological characteristics of the criminal. Sehubungan dengan penelitiannya mengenai pencurian, ia menemukan bahwa perbuatan mencuri biasanya berasal dari kebiasaan. Dalam satu penelitian kasus Lombroso menemukan jurang besar yang nyata tentang karakter pencuri yang berusia kanak-kanak. Kanak-kanak mulai mencuri dari jumlah yang kecil (sen), kemudian berlanjut pada jumlah yang semakin lama semakin besar dan akhirnya mencuri dalam jumlah yang sangat besar. Kecenderungan untuk menjadi seorang pencuri sudah terlihat pada usia yang sangat muda. Kebiasaan mencuri dimulai dengan mencuri/mengambil benda-benda/uang yang bernilai kecil di rumah. Lama kelamaan meningkat secara bertahap dan menjadi pencuri professional. Fakta ini berlawanan dengan pembunuh yang jarang membunuh pada usia yang sangat muda (kanak-kanak). Inilah yang menjadi alasan bahwa kanak-kanak di bawah usia pubertas yang melakukan pembunuhan lebih sedikit berbanding kanak-kanak pada usia sama yang melakukan pencurian. Lihat Cesare Lombroso, Crime Its Causes and Remedies, (Montclair New Jersey: Patterson Smith, 1910), 177 \& 178.

58 Ada berbagai definisi harta (مال) yang dikemukakan oleh ahli fiqh. Menurut pengertian bahasa harta ialah segala sesuatu yang dimiliki oleh manusia. Menurut Ibn Abidin dari ulama mazhab Hanafi, harta ialah sesuatu yang cenderung tabiat manusia kepadanya dan memungkinkan untuk mengadakannya pada waktu diperlukan. Menurut al-Syatibiyy dari ulama mazhab Maliki, harta ialah sesuatu yang berlaku padanya pemilikan dan si pemilik mampu mempertahankannya ketika diambil oleh orang lain di hadapannya. Menurut ulama mazhab Syafi'iy harta ialah segala sesuatu yang bermanfaat dan membantu karena ia bisa dimanfaatkan. Tidak disebut المال kecuali harta itu berharga dan dapat diperjualbelikan. Menurut ulama mazhab Hanbali harta ialah segala sesuatu yang bisa memberi manfaat dalam keadaan apapun. Lihat al-Syâtibiy, al-Muwâfaqat fi Usûl al-Ahkâm, Juz 2, (Mesir: Maktabah wa Matba'ah Muhammad Ali Sabih, t.th), 10. 
terpelihara, dipotong tangannya seperti halnya ia mencuri dalam jumlah banyak. ${ }^{59}$ Oleh sebab itu, ulama mazhab Zahiri berpendapat bahwa aspek penting dalam pencurian tidak terletak pada harta atau jumlah harta yang dicuri, tetapi mereka menilai pada hukum haram melakukan perbuatan mencuri.

\section{E. KESIMPULAN}

Para ulama terbagi pada tiga kelompok besar dalam menetapkan nisâb harta curian. Hadis-hadis Rasulullah SAW menjelaskan nilai harta berbeda yang menjadi ukuran minimal kemestian potong tangan. Dasar penilaian yang digunakan adalah emas dan perak. Penggunaan kedua benda ini memiliki alasan masing-masing dan alasan-alasan itu memiliki dasar yang kuat, sehingga mampu bertahan sampai sekarang. Dimulai dari nilai terendah yaitu 1/4 dinar, kemudian ada yang mengambil nilai tertinggi yaitu 1 dinar atau 10 dirham dan ada yang tidak menggunakan nisâb sama sekali. Ijtihad ulama dalam mengambil nilai terendah (الأخذ بأَقّ) dan mengambil nilai tertinggi (الأخذ بالأكثر) ataupun tidak menggunakan nisâb dalam menentukan nisâb harta curian ini termasuk ke dalam sikap berhati-hati (من المسالك الإحتياطة). Sikap berhatihati dalam masalah ini berkaitan dengan tuntutan syarak yang menghendaki sesuatu dalam jumlah yang jelas. Pengambilan nilai terendah dimaksudkan untuk berhatihati dalam memelihara kepentingan harta yang dicuri. Adapun mengambil nilai tertinggi dimaksudkan untuk memelihara kepentingan pemotongan tangan orang yang mencuri. Sedangkan tidak menggunakan nisâb merupakan sikap berhati-hati tidak hanya dalam menjaga si pelaku dari perbuatan maksiat tetapi juga dalam rangka memelihara harta. Sikap untuk memilih berhati-hati dalam menetapkan ukuran minimal potong tangan di antara nas yang berbeda-beda dan dengan kualitas yang berbeda-beda pula, senantiasa didukung oleh pertimbangan dan dalil-dalil akal.

\section{DAFTAR PUSTAKA}

\section{Al-Qur'ân al-Karîm}

Alrasid, Harun (pem.red), Himpunan Peraturan Perundang-undangan Republik Indonesia Menurut Sistem Engelbrecht. Jilid I, Jakarta: Ichtiar Baru van Hoeve, 2006.

al-Asqalaniy, Ibn Hajar, Fath al-Bâriy Syarh Sahîh al-Bukhâriy. Jilid 12, Kairo: Dâr al-

${ }^{59}$ Raudah Jamal al-Husairiy, Fiqh al-Hasan al-Basriy al-Muqârin ma'a al-Mazâhib al-Arba'ah, Juz 3, (Damsyiq: Dâr al-Kâlim al-Tayyib, 2002), 36. 
Manâr, 1999.

Al-Barâziy, Abi Sa'îd, al-Tahzîb fi Ikhtisar al-Mudawwanah. Dubai: Dâr al-Buhûth li alDirâsât al-Islâmiyah, 2002.

al-Bukhâriy, Sahîh al-Bukhâriy. Juz 4, Kairo: Dâr al-Hadîth, 2000.

Dahlan, Abdul Aziz, (et al.), Ensiklopedi hukum Islam. Jilid 4, Jakarta: Ichtiar baru Van Hoeve, 1997.

al-Dârimiy, Sunan al-Dârimiy. Juz 1, Kairo: Dâr al-Hadîth, 2000.

al-Farrâ', Abi Muhammad al-Husain Ibn Masud Ibn Muhammad Ibn, al-Tahzî̉ fi Fiqh al-Imâm al-Syâfi'iy, Jilid 7, Beirut: Dâr al-Kutub al-Ilmiyah, 1997.

Fauriy, Al-Muttaqa al-Hindiy al-Burhân, Kanz al-'Ummâl fi Sunan al-Aqwâl wa al-Af'âl. Juz 10, Beirût: Muassasah al-Risâlah, 1989.

al-Hanafiy, Ibn al-Humâm, Syarh Fath al-Qadîr, Juz 5, Beirût: Dâr al-Kutub al-Ilmiyah, 1995.

Hanbal, Ahmad Ibn, Musnad al-Imâm Ahmad Ibn Hanbal. Juz 2, Beirût: al-Maktab alIslâmiy, 1993.

al-Husairiy, Raudah Jamal, Fiqh al-Hasan al-Basriy al-Muqârin ma'a al-Mazâhib alArba ah. Juz 3, Damsyiq: Dar al-Kalim al-Tayyib, 2002.

Ibn Hayyan, Tafsîr al-Bahr al-Muhît. Jilid 3, Riyâd: Maktabah al-Nasr al-Hadîthah, t.th.

Ibn Hazm, al-Muhalla. Juz 11, Beirût: al-Maktab al-Tijâriy, t.th.

Ibn Qudâmah, al-Mughniy, wa al-Syarh al-Kabîr ala Matan al-Qan'u fi Figh al-Imâm Ahmad ibn Hanbal. Jilid 10, Beirut: Dar al-Fikr, 1984.

Ibn Qudâmah, al-Mughniy. Jilid 26, (Riyâd: Dâr al-'Ălim Kutub, 1998.

Ibn Rusyd, Bidâyat al-Mujtahid wa Nihâyat al-Muqtasid. Jilid 2, Beirût: Dâr al-Kutub alIlmiyah, 1997.

'Iyâd, Ibn Musa Ibn 'Iyâd, Syarh Sahîh Muslim li al-Qâdi 'Iyâd al-Musamma Ikmâl alMu'lim bi Fawâiid Muslim. Juz 5, Beirût: Dâr al-Wafâ', 1998.

al-Jassâs, Tafsîr Ăyat al-Ahkâm. Beirût: Dâr al-Fikr, t,th.

al-Kandahlawiy, Muhammad Zakariya, Aujâz al-Masâlik ila Muwatha`Mâlik. Juz 15, Damaskus: Dâr al-Qisâ', 2003.

al-Kasâniy, Ibn Mas'ûd, Badâi' al-Sanâi' fi Tartîb al-Syarâi'. Juz. 9, Beirût: Dâr al-Kutub al-Ilmiyah, 1997.

Lashin, Mûsa Syahîn, Fath al-Mun'im Syarh Sahîh Muslim. Jilid 7, Kairo: Dâr alSyurûq, 2002.

Lombroso, Cesare, Crime Its Causes and Remedies. Montclair New Jersey: Patterson Smith, 1910

Mahmood, M, Enforcement of Hudood Practice and Procedure. Lahore: Pakistan Law Times Publications, 1984.

Mahmood, Tahir, Criminal Law in Islam and the Muslim World A Comparative Perspective. (Jamia Nagar Delhi: Qazi Publishers, 1996

Muslim, Sahîh Muslim ma'a Syarhihi al-Musamma Ikmâl al-Mu'allim. Juz 6, Beirût: Dâr 
al-Kutub al-Ilmiyah, 1994.

al-Mutî'iy, Muhammad Najib, Kitâb al-Majmû' Syarh al-Muhazzab li al-Syirâziy. Juz 19, al-Fijâlah, al-Maktabah al-Alamiyah., t.th.

al-Naisaburiy, al-Mustadrak ala al-Sahîhain. Juz. 4, Beirût: Dâr al-Kutub al-Ilmiyah, 1990

al-Nasâiy, Sunan al-Nasâiy. Juz 4, Kairo: Dâr al-Hadîth, 1999.

al-Qattân, Mannâ', Tarîkh al-Tasyrî́ al-Islâmiy. Maktabah al-Ma'ârif, Riyâd, 1992.

al-Qurtubiy, al-Jâmi' al-Ahkâm al-Qur'ân. Juz 2, Beirût: Dâr al-Kâtib al-Arabiy, 1967.

al-San'âniy, Abu Bakr Abd al-Razzâq ibn Hammâm ibn Nâfi', al-Musannif. Beirût: Dâr al-Kutub al-Ilmiah, 2000.

Syaibah, Muhammad Ibn Abi, al-Musannif fi al-Ahâdith wa al-Atsâr. Beirût: Dâr alFikr, 1989

al-Syâfi'iy, Muhammad ibn Idris, al-Risâlah. Mesir: Mustafa al-Bâby al-Halabiy, 1940.

al-Syâtibiy, al-Muwâfaqât fi Usûl al-Ahkâm. Juz 2, Mesir: Maktabah wa Matba'ah Muhammad Ali Sabih, t.th. 